\title{
Evaluating the superiority of honey over silver sulphadiazine dressing in shortening healing duration of burn injury: an evidence-based case report
}

Sandy S. Sopandi

Faculty of Medicine, Universitas Indonesia, Jakarta, Indonesia

\begin{abstract}
Abstrak
Latar belakang: Luka bakar adalah masalah kesehatan global yang diasosiasikan dengan morbiditas dan mortalitas tinggi. Madu telah digunakan sejak lama dalam penanganan luka karena kemampuannya mempercepat penyembuhan dan mencegah infeksi. Studi ini dilakukan untuk mengevaluasi efektivitas madu topikal dalam mempersingkat durasi penyembuhan luka bakar dibandingkan silver sulfadiazine (SSD).
\end{abstract}

Metode: Pencarian database Pubmed dan Proquest dilakukan untuk mengidentifikasi studi-studi yang relevan. Studi yang didapatkan kemudian dinilai berdasarkan validitas, importance, dan level of evidence.

Hasil: Terdapat dua studi yang mendukung keunggulan madu dibandingkan SSD dalam mempersingkat durasi penyembuhan luka. Meskipun demikian, kualitas individual studi-studi yang terlibat dinilai rendah.

Kesimpulan: Madu merupakan terapi alternatif untuk memperpendek durasi penyembuhan luka bakar. Studi lebih lanjut dibutuhkan untuk mendukung aplikasi klinis kesimpulan ini. (Med J Indones. 2013;22:243-7. doi: 10.13181/mji.v22i4.608)

\begin{abstract}
Background: Burn injury is a global health problem associated with major morbidity and mortality. Honey has long been used in wound management due to its ability to accelerate healing rates and prevent infection. This study is conducted to evaluate the efficacy of honey dressing in shortening healing duration of burn injury compared to silver sulphadiazine (SSD).

Methods: A PubMed and Proquest database search was conducted to identify relevant studies. The studies were then appraised and ranked based on their validity, importance, and level of evidence.

Results: The two studies appraised in this paper supported the supremacy of honey against SSD in shortening healing duration. However, the individual quality of studies involved was low.

Conclusion: Honey is an alternative treatment in shortening burn wound healing duration. Further studies are needed to support clinical application of this conclusion. (Med J Indones. 2013;22:243-7. doi: 10.13181/mji.v22i4.608)
\end{abstract}

Keywords: Burn injury, healing duration, honey, silver sulfadiazine

Burn injury is a global public health problem, contributing to approximately 195,000 deaths annually. The majority of burn morbidity and mortality originate from the South-East Asia region, particularly in developing countries such as Indonesia. Even nonfatal burns can cause considerable morbidity such as prolonged hospitalization and disability, leading to a significant socioeconomic impact. ${ }^{1}$

Since ancient times, honey has been used to manage both acute and chronic wound, including burn wound. Many studies have been published regarding its efficacy in accelerating healing rates and preventing infection. It provides a moist wound environment, enhances tissue growth and epithelization with fewer inflammatory changes, and has a debriding action. ${ }^{2}$

Silver sulphadiazine (SSD) is a widely used topical treatment for burn injury which is available at the majority of primary health care centers throughout Indonesia. It is, however, associated with several adverse effects, such as hepatic or renal toxicity and leucopenia, especially in the treatment of large wounds. ${ }^{3}$

The benefit of honey has a biological plausibility. Moreover, it is not associated with adverse effects like those of SSD. However, the therapy still lacks replicable and applicable evidence to guide clinical practice.

\section{Clinical scenario}

A 23-year-old male was brought to a clinic after a fire broke out at his house and diagnosed with a $15 \%$ superficial and $10 \%$ partial-thickness burn injury on his legs. After oral rehydration and wound cleansing, the attending physician used honey for wound dressing.

\section{Clinical question}

The proposed question in this study is whether honey dressing is more effective than SSD in shortening healing time of superficial or partial-thickness burn injury. 
Table 1 . Search strategy implemented, search conducted June $15^{\text {th }} 2013$

\begin{tabular}{clcc}
\hline Database & \multicolumn{1}{c}{ Search strategy } & Hits & Selected articles \\
\hline Pubmed & ("burns"[MeSH Terms] OR "burns”[All Fields] OR "burn”[All Fields]) & 16 & 2 \\
& $\begin{array}{l}\text { AND ("honey"[MeSH Terms] OR "honey"[All Fields]) AND ("silver } \\
\text { sulphadiazine"[All Fields] OR "silver sulfadiazine”[MeSH Terms] }\end{array}$ & & \\
& $\begin{array}{l}\text { OR ("silver"[All Fields] AND "sulfadiazine"[All Fields]) OR "silver } \\
\text { sulfadiazine"[All Fields]) }\end{array}$ & & \\
\hline Proquest & burn AND honey AND silver & 18 & 0 \\
\hline
\end{tabular}

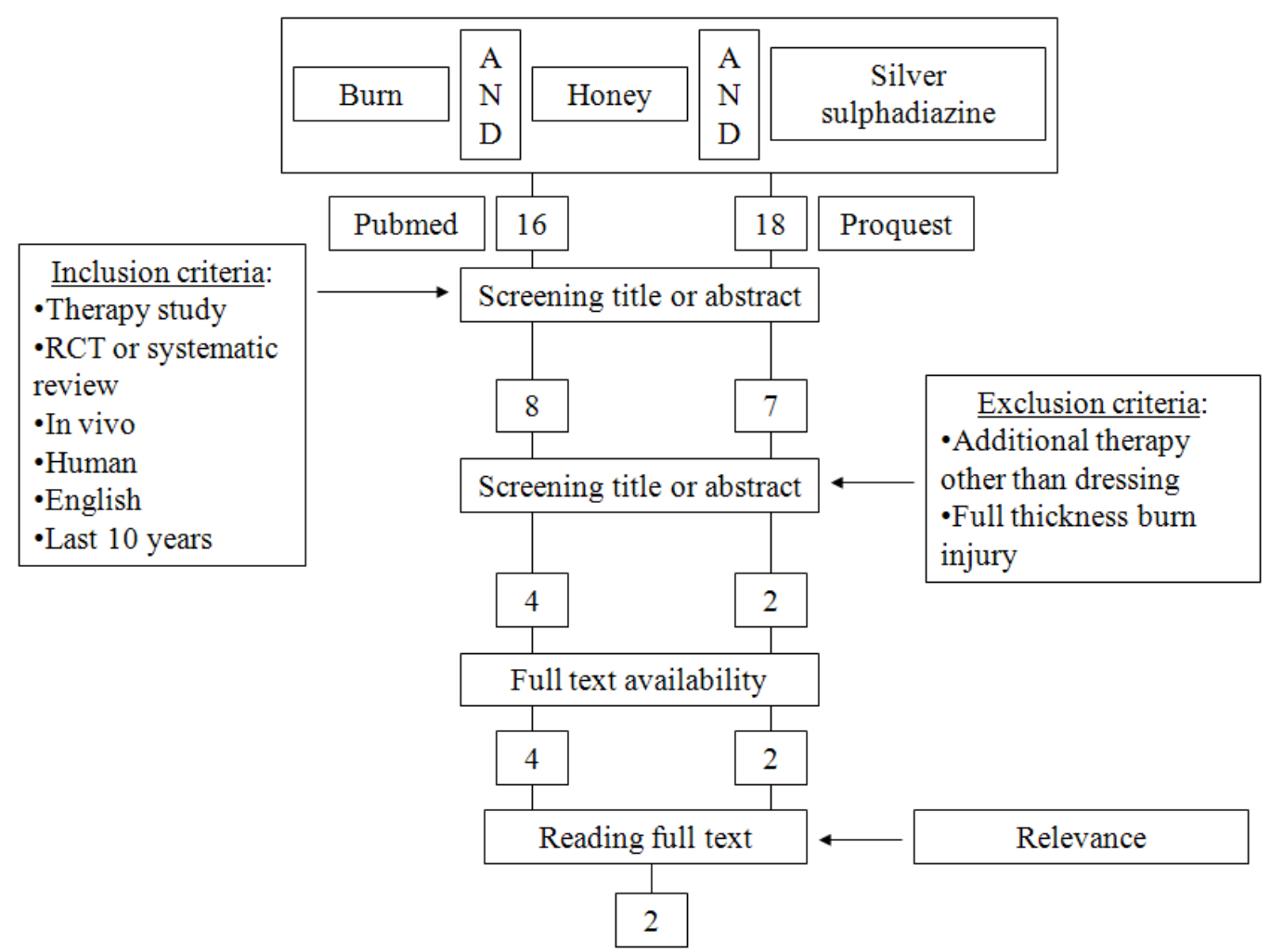

Figure 1. Flowchart search strategy, conducted June $15^{\text {th }} 2013$

\section{METHODS}

\section{Search strategy}

The author searched PubMed and Proquest databases for studies published from 2003 to July 2013 (Table 1 and Figure 1).

\section{Critical appraisal}

The author appraised the validity and importance of chosen studies using a standardized form published by the University of Oxford's Centre of Evidence Based Medicine. The outcome that was evaluated in the randomized controlled trials (RCT) studies was the presence of wound healing in 21 days after the onset of burn injury, taking into consideration the duration of the proliferative phase of wound healing. While for the systematic review and meta-analysis, a different form was used. ${ }^{4}$ The level of evidence was also graded for each study according to the American Society of Plastic Surgeon's guidelines (Table 2 and 3). ${ }^{5}$

\section{RESULTS}

The author conducted a search on PubMed and Proquest databases, limited the search on human studies in the form of RCT or systematic reviews published in the last 10 years, and then excluded studies of burn injury other than superficial or partial thickness burn and those performing therapy other than topical honey and SSD. Ultimately, the author appraised two studies.

An RCT by Malik, et al ${ }^{3}$ compared the healing duration between burn wounds treated with honey and those with SSD. This study included a total of 150 patients 
Table 2. Critical appraisal of RCT: validity, importance, and level of evidence

\begin{tabular}{|c|c|c|c|c|c|c|c|c|c|c|}
\hline \multirow{2}{*}{ Articles } & \multicolumn{5}{|c|}{ Validity } & \multicolumn{4}{|c|}{ Importance } & \multirow[t]{2}{*}{$\begin{array}{l}\text { Level of } \\
\text { Evidence }\end{array}$} \\
\hline & 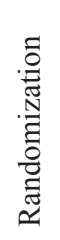 & 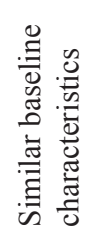 & 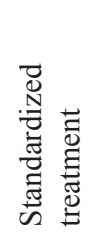 & 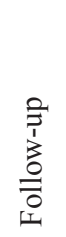 & $\begin{array}{l}\stackrel{\infty}{\Xi} \\
: \Xi \\
\Xi\end{array}$ & 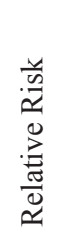 & 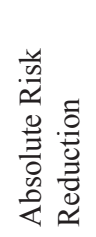 & 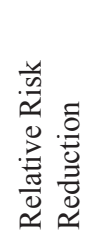 & 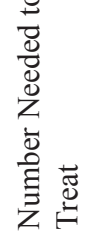 & \\
\hline Malik KI, et al. & + & + & - & + & $?$ & 1.28 & 0.21 & 0.28 & 5 & II \\
\hline
\end{tabular}

Table 3. Critical appraisal of systematic review and meta-analysis: validity, importance, and level of evidence

\begin{tabular}{|c|c|c|c|c|c|c|c|}
\hline \multirow[b]{2}{*}{ Articles } & \multicolumn{4}{|c|}{ Validity } & \multicolumn{2}{|c|}{ Importance } & \multirow{2}{*}{$\begin{array}{l}\text { Level of } \\
\text { Evidence }\end{array}$} \\
\hline & & & & & OR (95\% CI fixed) & Homogeneity test & \\
\hline & 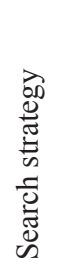 & 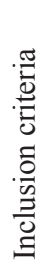 & 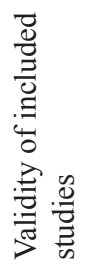 & 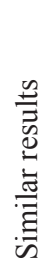 & & & \\
\hline Wijesinghe $\mathrm{M}$, et al. & + & \pm & \pm & + & $7.2(4.1-12.9)$ & $\begin{array}{c}\mathrm{chi}^{2}=12.3, \mathrm{df}=3(\mathrm{p} \\
=0.01), \mathrm{I}^{2}=75.7 \%\end{array}$ & II \\
\hline
\end{tabular}

with two second-degree burns of similar surface area on their bodies. All burns had occurred within 24 hours before treatment was initiated. Other than the dressing type, the treatment protocol is similar between the two groups. This, however, was contradicted by a statement saying that eight patients in honey group and 29 patients in SSD group were skin grafted. With every dressing, the wound's nature of epithelialization was observed and measured. It was not stated whether the evaluator was blinded to the treatment given. ${ }^{3}$

Since the number of patients analysed at the end of the study was the same as the initial number of patients included at the beginning, it can be inferred that there were no drop outs. The average healing duration was $13.47 \pm 4.06$ days for honey group and $15.62 \pm 4.40$ days for SSD group $(\mathrm{p}<0.0001){ }^{3}$

Another systematic review and meta-analysis study by Wijesinghe, et $\mathrm{al}^{6}$ compared the efficacy of honey with other dressings including SSD, bio-occlusive moisture permeable polyurethane dressing (OpSite), autoclaved potato peel bandages, and amniotic membrane in treating superficial and partial thickness burn injury. The inclusion criteria of this review did not specify the uniformity of included studies in terms of burn grade ("...the burns was either partial thickness or superficial..."), the time of admission, and the method of dressing. ${ }^{6}$

The systematic review evaluated a total of eight studies, all of which had poor quality as shown by their Jadad score of 1 . The studies lacked description of the randomization procedure, pre-defined primary outcomes, sample size calculations, evidence whether wound assessment was blinded to treatment, flow of participants, and subjects who withdrew. ${ }^{6}$

Out of all studies, five studies compared honey to SSD. One of the secondary outcomes evaluated in this review was the 15-day healing rate in SSD comparator studies, where the pooled fixed effect odds ratio was $7.2(95 \%$ CI 4.1 to 12.9) in favour of honey. The homogeneity test statistic was $\mathrm{chi}^{2}=12.3, \mathrm{df}=3(\mathrm{p}=0.01), \mathrm{I}^{2} 75.7 \%$ (95\% CI 32.9 to 91.2 ), and the random effects pooled odds ratio was $8.0,95 \%$ CI 2.6 to $25.0 .^{6}$

This review concluded that honey demonstrates greater efficacy when compared to other dressings, including SSD. However, the poor quality of individual studies included in this meta-analysis limit the clinical application of this review. ${ }^{6}$ 


\section{DISCUSSION}

Honey has been used as a topical treatment for wounds, including burn injury, for centuries. Its high osmolarity, hydrogen peroxide content, and high acidity prevent bacterial growth. It also provides substrates needed for macrophages' antibacterial activity. Honey provides a non-adherent interface between the wound bed and the dressing, creating a moist environment for optimal healing and preventing tearing of newly-formed tissue during dressing changes. Honey may also reduce odours as well as swelling, and provide pain relief., ${ }^{3,7}$ Furthermore, it is associated with a more pleasing scar formation. It is also non-toxic, non-irritating, and easily available. ${ }^{9}$ Another advantage is that honey costs less than SSD, i.e. ranging from approximately $\mathrm{Rp} 20,000$ (2 USD)/ $\mathrm{kg}$ to $\mathrm{Rp} 150,000$ (15 USD)/kg compared to SSD's Rp 35,000 (3.5 USD)/tube (35 gr) in Indonesia. ${ }^{10}$

The benefits of honey dressing for burn injury have been evaluated in a number of studies. In a biochemical study by Nagane, et $\mathrm{al}^{9}$ honey dressing proves to be accelerating the process of healing by reducing oxidative stressful state. Compared to those treated with SSD, patients treated with honey were observed to have lower serum lipid peroxidation product and uric acid, both of which are associated with oxidative stress. Honey usage was also associated with slower rise in ceruloplasmin level, another indication of ongoing free radical activity.

Another study by Baghel, et $\mathrm{al}^{7}$ declared similar superiority of honey in improving wound healing. The average healing duration in patients treated with honey was 18.16 days, compared to 32.68 days in the SSD group. Wound swab culture in this study showed that honey managed to sterilize the wound faster. However, this study could not be included in the appraisal since it didn't have the data regarding the number of patients healed before 21 days, which was needed to evaluate the importance.

A retrospective study was conducted by Gupta, et $\mathrm{al}^{8}$ on patients who had been treated with either honey or SSD over a period of 5 years. In that study, patients treated with honey showed an average healing duration of 18.1 days compared to 32.6 days in the SSD group. This study was not included in the appraisal because of the same reason as the previous study by Baghel et al.

As for the RCT and systematic review/meta-analysis included in this study, both results supported honey as the superior dressing for burn injury. However, the RCT by Malik, et al ${ }^{3}$ didn't specify the blinding given to the evaluator. Blinding may be difficult to accomplish, since the difference between these two topical treatments is obvious. To solve this dilemma, wound evaluation should be done by a third party during dressing changes when the treatment given is unnoticeable. To boot, this study didn't consider the effect of grafting on the difference of wound healing duration.

The systematic review by Wijesinghe, et $\mathrm{al}^{6}$ also showed the superior efficacy of honey, although it also criticized the low quality of individual studies included in the review. The burn grade was not equated, as the authors included both superficial and partial-thickness burns in their search. Other studies had the same drawback, i.e. they did not standardize burn thickness included in their study, ${ }^{7-9}$ whereas a superficial burn cause less damage to the skin compared to a partialthickness burn. This results in a supposedly shorter healing time, creating a possible bias in the result. Moreover, it also demands the need to differentiate the method of wound healing evaluation between the two types of burn.

Another obstacle in utilizing honey as a mainstay therapy in burn management is the many varieties of honey in Indonesia. In international studies, New Zealand's Manuka honey is often cited as having particularly high antibacterial properties, even against Methicillin-resistant Staphylococcus aureus (MRSA) and Vancomycin-resistant Enterococci (VRE). ${ }^{3,6}$ Several studies have showed that Indonesian local honey has similar antibacterial characteristics to Manuka honey. ${ }^{11,12}$ As infection control is one of the vital factors in optimizing wound healing, this characteristic supports to the potential of local honey in accelerating healing process. Further studies are indicated to evaluate individual efficacy of the many varieties of local honey in treating burn injuries.

In conclusion, based on the studies appraised in this case report, the author concludes that honey dressing is a superior alternative compared to SSD in shortening healing duration of burn injury. In order to be reinforced for clinical application, RCTs of higher quality need to be conducted, with similar baseline characteristics in terms of burn grade, surface area, time of admission, and evaluator blinding.

\section{Acknowledgment}

The author wishes to thank Peter Pratama and Johannes A. Biben for their unrelenting patience and assistance in composing this study. 


\section{REFERENCES}

1. World Health Organization [Internet]. Burns [updated 2013 May; cited 2013 Jun 16]. Available from: http://www.who. int/mediacentre/factsheets/fs365/en/

2. Jull AB, Walker N, Deshpande S. Honey as a topical treatment for wounds. Cochrane Database Syst Rev. 2013;2: CD005083.

3. Malik KI, Malik MAN, Aslam A. Honey compared with silver sulphadiazine in the treatment of superficial partialthickness burns. Int Wound J. 2010;7(5):413-7.

4. Centre for Evidence Based Medicine [Internet]. Critical appraisal [updated 2013 Jun 3; cited 2013 Jun 20]. Available from: http://www.cebm.net/index.aspx?o=1157

5. American Society of Plastic Surgeons [Internet]. ASPS evidence rating scales [cited 2013 Jun 29]. Available from: http://www.plasticsurgery.org/formedical-professionals/legislation-and-advocacy/healthpolicy-resources/evidence-based-guidelinespracticeparameters/description-and-development-of-evidencebased-practice-guidelines.html

6. Wijesinghe M, Weatherall M, Perrin K, Beasley R. Honey in the treatment of burns: a systematic review and metaanalysis of its efficacy. N Z Med J. 2009;122(1295):47-60.
7. Baghel PS, Shukla S, Mathur RK, Randa R. A comparative study to evaluate the effect of honey dressing and silver sulfadiazene dressing on wound healing in burn patients. Indian J Plast Surg. 2009;42(2):176-81.

8. Gupta SS, Singh O, Bhagel PS, Moses S, Shukla S, Mathur RK. Honey dressing versus silver sulfadiazene dressing for wound healing in burn patients: a retrospective study. J Cutan Aesthet Surg. 2011;4(3):183-7.

9. Nagane NS, Ganu J V, Bhagwat VR, Subramanium M. Efficacy of topical honey therapy against silver sulphadiazine treatment in burns: a biochemical study. Indian J Clin Biochem. 2004;19(2):173-6.

10. MIMS Indonesia [Internet]. Burnazin [cited 2013 Jun 29]. Available from: http://www.mims.com/Indonesia/drug/ info/Burnazin/?q=silver\&type $=$ brief

11. Diah KA, Sundoro A, Sudjatmiko G. Antibacterial activity of Indonesian local honey against strains of P. aeruginosa, S. aureus, and MRSA. Jurnal Plastik Rekonstruksi. 2012;1(2):177-81.

12. Sundoro A, Nadia K, NurA, Sudjatmiko G, Tedjo A. Comparison of physical-chemical characteristic and antibacterial effect between Manuka honey and local honey. Jurnal Plastik Rekonstruksi. Jurnal Plastik Rekonstruksi. 2012;1(3):341-7. 